\title{
Microfinance and Women Empowerment in Zimbabwe: A case of Women Development Fund in Umguza district
}

\author{
Joyce Selome ${ }^{a}$, Nevel Tshuma ${ }^{b}$ \\ Institute of Development Studies, National University of Science and Technology, \\ No_ 38 Duncan Road, Suburbs, Bulawayo, Zimbabwe \\ a,bE-mail address: selomejoyce@yahoo.com , tshumez@gmail.com
}

\begin{abstract}
The gender dimension of poverty focuses on the dilemma of women, their numerous roles as women and their role in dealing with poverty. In many developing countries, women are discriminated upon in terms of their access to capital means of production; basic needs support, employment opportunities and access to credit facilities. In Zimbabwe, like in many developing countries, empowering women through micro-credit finance is viewed as a means of reducing women poverty, empowering them, reducing their vulnerability and improving their well-being especially in the rural areas. This paper discusses the role of the government of Zimbabwe in empowering rural women through the introduction Women Development Fund (WDF). The study was carried out in Umguza district in Matabeleland North province of Zimbabwe. The study employed mainly purposive sampling and data was collected using questionnaire, key informant interviews, focus group discussion observation and oral history. Research revealed that WDF as a strategy has made a difference in the livelihoods of the recipients through initiation of income generating projects. However the major handicap with WDF is that the amount of money given are small and that it was employed in isolate hence the need to have complementary initiatives such as capacity building, market networking among others.
\end{abstract}

Keywords: Women Development Fund; Umguza; Empowerment; Microfinance

\section{INTRODUCTION}

Women represent $70 \%$ of the world's poor (UNIFEM, 2012) due to unequal access to economic opportunities in both developed and developing countries. Internationally, there is a link between poverty alleviation in countries and the development of their female human capital. Although economic progress can improve the status of women, it is also true that a country cannot sustainably develop if its women are left behind (Boserup, 1970). Focusing on women in the provision of credit assistance can achieve more rapid pro-poor economic growth than gender neutral policies (UNIFEM, 2012). Investing in women and girls, in their education, health and access to assets and jobs has a multiplier effect on productivity, efficiency and sustained economic growth in developing countries (World Bank, 2006). The commitment by the world to empower women and end gender inequalities is explicit in Millennium Development Goal 3. 
According to the United Nations Industrial Development Organization (2003), women and girls constitute three fifth of the world's poor. Their poverty level is worse than that of men as clear gender disparities in education, employment opportunities and decision making power exist. Magaji (2004) argues that women have been the poor sex throughout the 20th Century and have constituted a substantial majority of the poor since poverty was first recognized.

\section{LITERATURE REVIEW}

In line with the millennium development goal number three, the government of Zimbabwe, through the ministry of Woman Affairs, set up a Women Development Fund. This fund was set up to assist women who were already entrepreneurs and those who wanted to start income generating projects. The objective of the fund is to empower and capacitated disadvantaged women by providing collateral free loans. The provision of such credit schemes by the government of Zimbabwe is in line with the global practice. There are many examples of micro credit finance globally, however the most prominent ones include; Grameen Bank, BRAC, BancoSol, ASA and Bandhan. Injection of micro loans to address poverty and gender inequality has become a common solution globally. Micro credit schemes come as a reaction strategy to the failure by many development intervention strategies to include women in planning and implementation. The aim of this approach is to enable women to earn direct income, there by giving them a voice in the community and enabling them to participate in the public sphere and in decision making. Discussion of micro credit schemes borrows much from the success of Grameen Bank in Bangladesh. This model has been replicated not only in Bangladesh but in many countries across the globe including Zimbabwe.

Microfinance is defined by Otero (1999) as the provision of financial services to lowincome poor and very poor self-employed people. Schreiner and Colombet (2001) share a similar view when they view micro financing as an attempt to improve access to small deposits and loans for poor households neglected by the banks and other formal financial institutions.

Rankin (2001) observe that micro credit has become one of the recognized tools of addressing poverty in developing countries. Gail (2005) further buttress this view by arguing that the year 2005 was United Nations' International year of micro-credit. In announcing year 2005 as a year of micro credit, former UN secretary general Koffi Anan observed that:

"The stark reality is that most poor people in the world still lack access to sustainable financial services, whether it is savings, credit or insurance. The great challenge before us is to address the constraints that exclude people from full participation inthe financial sector....

Together, we can and must build inclusive financial sectors that help people improve their lives."

Scholars who have conducted studies across the globe argue that microfinance has played a positive role in empowering women and alleviating poverty. A case in point is the work by Amin and Pebley (1994) in Bangladesh which showed that the membership of Bangladesh Rural Advancement Committee (BRAC) has had a positive impact on women in decision making as well as in gaining control of capital resources. This has altered the perception of women in the community as they are seen as income earners, making them a good source of financial resource. The same sentiments are expressed by Naved (1994) who posits that women borrowers felt their status at household level had improved as a result of income earnings from income generating projects. As a result of these projects, women gained control of the income 
and participated in household decision making (Osmani 1998). Naila Kabeer (2005) argues that microfinance offers an effective alternative of achieving change to poor rural women, be it economically, socially as well as politically. Microfinance's ability to build up organizational capacity for women is perceived as an avenue for their social mobilization that many other development intervention strategies failed to achieve. In the study on the socio-economic impacts of microfinance on women-borrowers conducted by Islam (1999), findings showed that microfinance intervention brought about positive impacts on borrowers. Quantitative changes were observed in the income they earned, land ownership and accumulation of assets. In the same vein, qualitative improvements were observed in the form of improved housing conditions, better sanitary conditions, better educational facilities for children and improved skills.

Inspite of these positives, some scholars have argued that the impacts of microfinance must not be read in isolation as families are also engaged in other activities that can bring about financial gains (Islam 1999). Zaman (2000) further observes that the impacts of microfinance differ depending on the social status of the borrower. The poor and the poorest benefit less from the loans as they have a higher degree of financial constraints than the relatively better off women. This prevents the poorer from investing the loans in high return activities as they have to satisfy their basic needs first before investing. Osmani (1998), used Grameen Bank as a case in point, to conclude that the larger part of the loan was not invested where it was intended and the many beneficiaries borrow more than they invest.

Microfinance as a tool of poverty reduction and women empowerment has long been criticised. The idea that the poor are entrepreneurs has no bases and foundation. Ditcher (2006) argues that the loans are too small to make a difference. Meade (2000) posits that the most difficult thing is to turn a loan into profit. The fact that microfinance is heavily reliant on subsidies poses questions on its sustainability in the long run. Also they have been heavily criticised for failing to reach the extremely poor. However, it is fundamental to note that microfinance is only a development strategy; it cannot be a solitary solution to poverty problems.

\section{METHODOLOGY}

This article is based on the data collected in uMguza district in Matabeleland North province of Zimbabwe in May 2013. The approach was both quantitative and qualitative. Literature review shaped the questions in the data collection instruments. Data collection was through in-depth interviews, focus group discussions and questionnaires and field observation. The WDF Income generating projects were scattered and widely dispersed throughout the rural heartland of uMguza. Accessibility of some of the Income generation projects was a problem due to the bad state of the roads. This created logistic problems in the mobilisation of the respondents thereby warranting the use of convenience and purposive sampling for the researcher administered questionnaires. In light of the preceding, wards 4, 5 and 14 were selected for the questionnaires and focus group discussion. As key informants the following officials were interviewed from the Ministry of Women Affairs Gender and Community Development:

(i) The Ministries' Provincial Development Officer for Matabeleland North.

(ii) Provincial Administrative Officer for Women Affairs.

(iii) District Development Officer for Umguza District 
(iv) Community Development Officer for Umguza District.

(v) 3 Ward Co-odinators Of Umguza District for ward 4, 5 and 14.

(vi) 3 Post Office Savings Bank officials who disbursed the revolving Fund administered the repayment of it.

The research targeted about 50 groups of beneficiaries who are engaged in various forms of income generating activities ranging from gardening to poultry. Individual and group discussions were held with entrepreneurs. Important activities were observed and documented.

\section{RESULTS AND DISCUSSION}

\section{1. Demographic data}

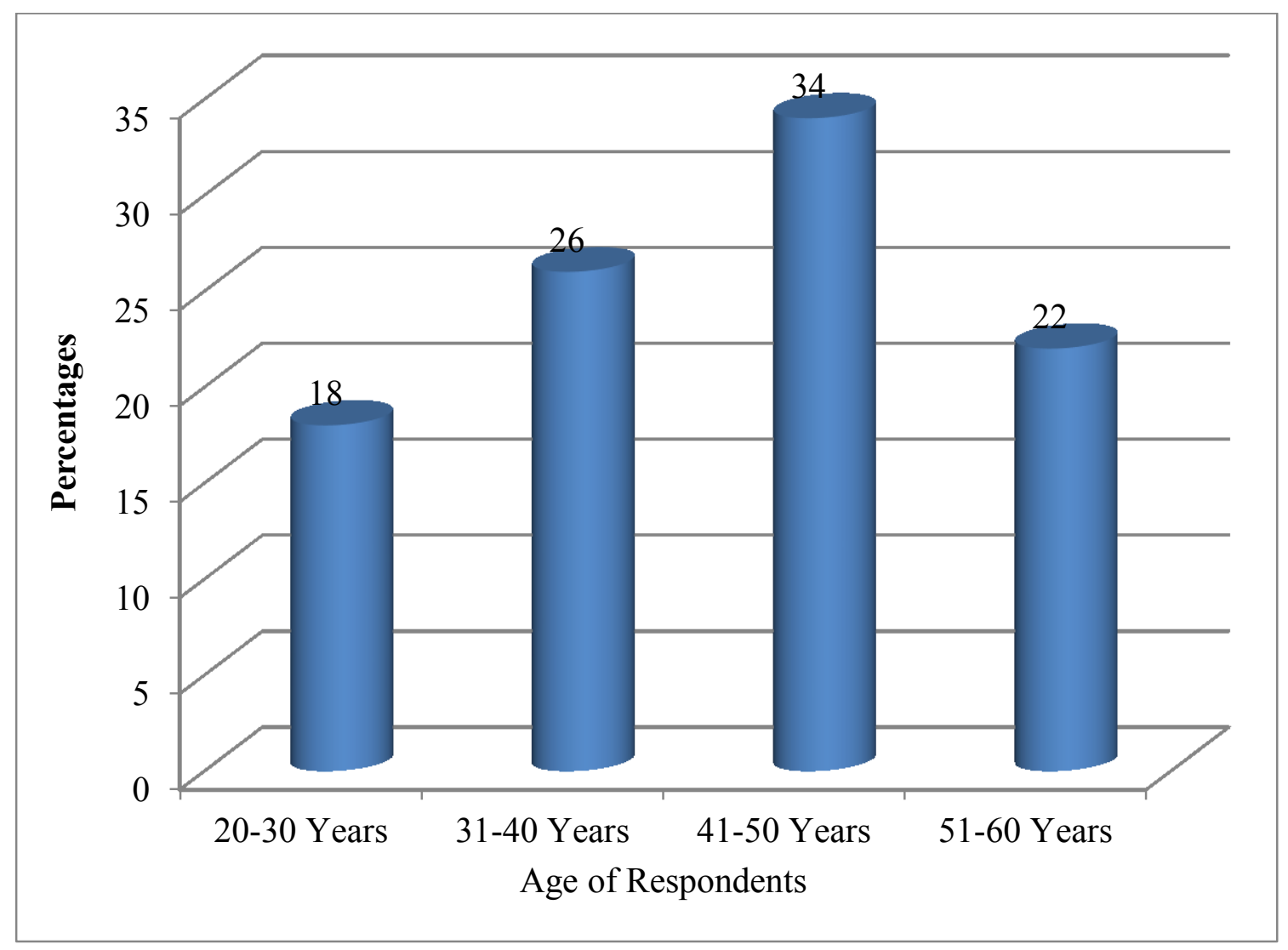

Fig. 1. Age of respondents.

The study showed that $18 \%$ of the respondents were $20-30$ years old. $26 \%$ of the respondents fell within the 31-40 age range. $34 \%$ of the respondents fell within the 41-50 age range. $22 \%$ of the respondents were in the range 51-60 years and there was no respondent in the sixty one plus age group. The research findings show that the majority of the respondents fell within the 41-50 age groups which are dominated by able bodied women. The explanation for a small percentage in the 20-30 age groups according to the Ministry of Women Affairs informants is that most young adults usually apply for loans from the Ministry of Youth since 
that Ministry has a special loan for all youths for income generating projects. Moreover the 61 plus are not able to work and most of them do not have adequate identity documents required at project proposal submission stage.

The findings showed that $70 \%$ of the women were unemployed and only $30 \%$ of the beneficiaries were gainfully employed. Employment levels had a bearing on repayment of the loan. Employed beneficiaries were able to use money from their incomes if ever met with challenges. They used their salary to repay the fund in case of low project profits, whilst those that failed to repay the fund only relied on the staggering profits to repay and if ever met with challenges they either loaned money from community clubs to resuscitate the project or completely abandoned the project and shared the small profits.

\section{2. Amount disbursed}

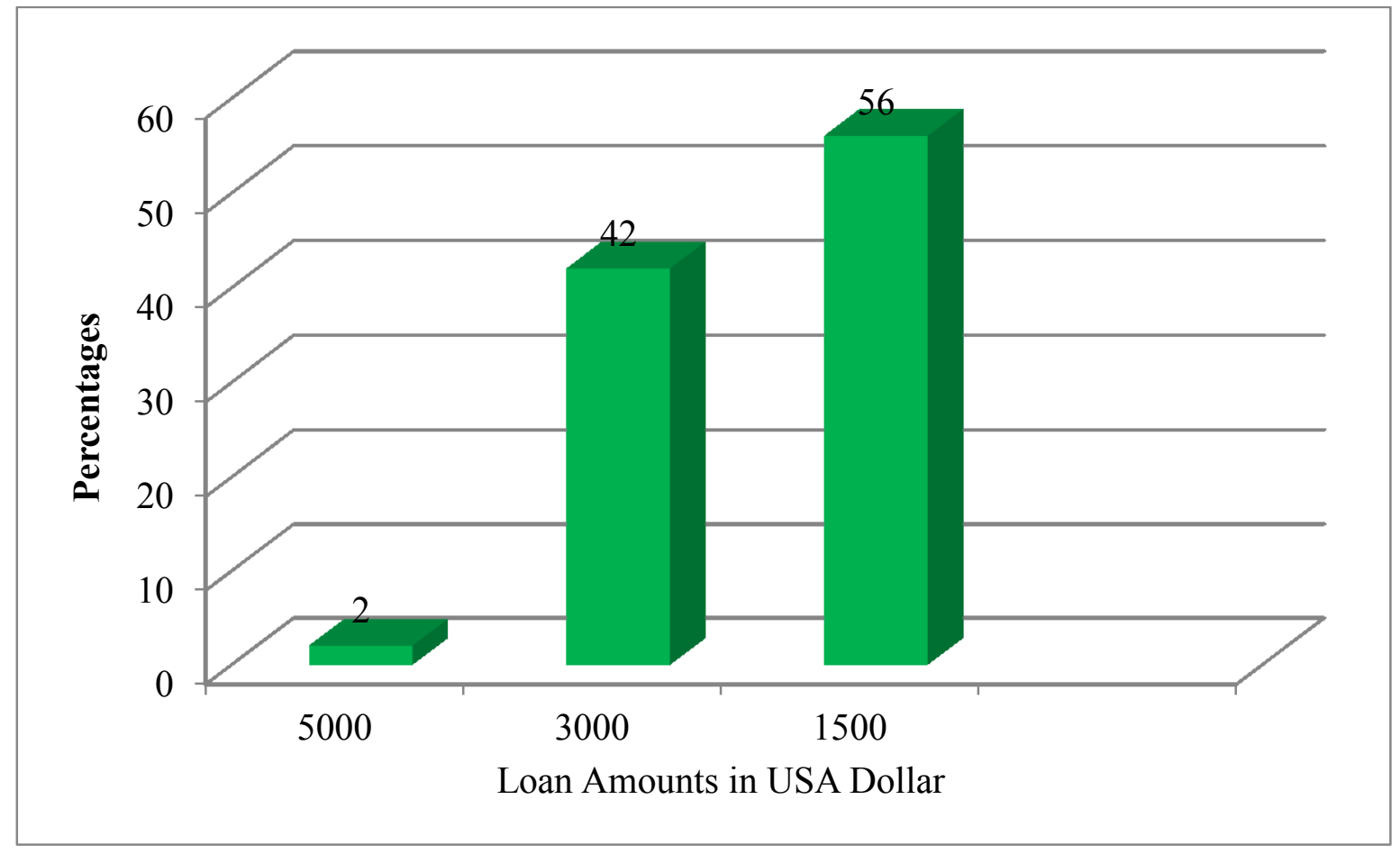

Fig. 2. Amount disbursed.

Figure 2 below shows the amount of money that was disbursed to the beneficiaries per group. $56 \%$ of the beneficiaries were given $\$ 1500$ dollars for their projects, $42 \%$ benefitted $\$ 3000$ and $2 \%$ got $\$ 5000$. Beneficiaries expressed that they expected to be given money according to their project proposals which they submitted at the Ministry of Women Affairs Gender and Community Development. On the contrary the Ministry reduced the loans applied for and gave them less than they had applied for citing reasons of insufficient loan for the whole country. According to the beneficiaries insufficient amount of money for the projects caused some groups to immediately split. The groups who split shared the $\$ 1500$ and diverted the money to their personal issues instead of funding the projects. The few that did not spilt engaged in poultry rearing and gardening projects using the $\$ 1500$. The challenge was that they could not afford to adequately plan for the projects due to insufficient funds. For example purchasing of the equipment for fowl runs, chicken feed and tools for their gardening was a 
great challenge. As a result some of the beneficiaries quit their projects at an infant stage for fear of failing to meet the Ministry's expectations.

\section{3. Adequacy of the Loan and Utilisation of the Loan}

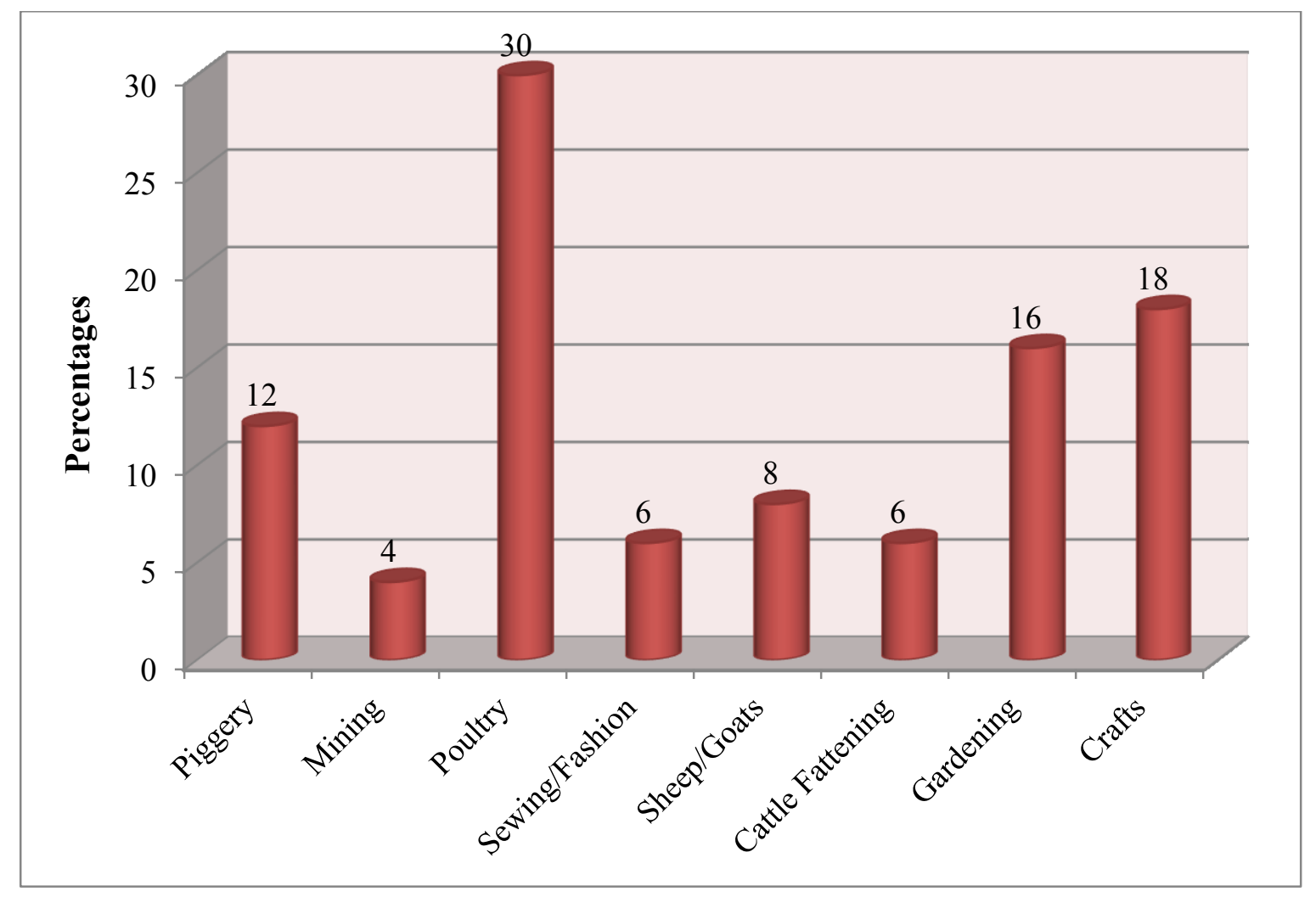

Fig. 3. Projects undertaken.

Most respondents interviewed seemed to hold the view that the funds were insufficient for the projects that they were engaged in. $64 \%$ of the beneficiaries expressed that the money was insufficient and $36 \%$ percent said it was sufficient for their projects. Insufficient loans have a bearing on the sustainability of the projects. It was inevitable for beneficiaries to borrow working capital from other loan sharks in the community to sustain their projects. Inadequate funds therefore caused failure in planning for the project. Beneficiaries stated that because they received fewer funds than expected they were not able to work on markets linkages and transport to the markets. As a result transportation costs eroded the very little profits that they made since markets were too far from where they operated from.

Pricing of products became a topical issue as the groups tagged their commodities higher so as to try and recover from the cost they incurred as a result of inadequate loan. Groups that were involved in market gardening were mostly affected as they lacked storage facilities for their vegetables.

The beneficiaries in the 3 wards engaged in 8 different projects as shown in figure 3 below. According to the Ministry of Women Affairs, large scale projects like mining and piggery are given large sums of money especially if the projects already existed on the ground. 
The majority of beneficiaries who received $\$ 1500$ engaged in poultry projects as it was regarded a cheaper option in relation to the loan disbursed. However, the minority of the respondents who held a diverging view and felt the money was adequate were mostly the employed. They used their personal money from their income to augment the loan from the ministry hence they ran the mining and piggery projects.

\section{4. Project Viability}

$32 \%$ of the beneficiaries were of the view that their projects were viable and $68 \%$ said their projects were not viable. It is imperative to acknowledge that failure of most projects was due to small amounts disbursed for the applied projects, as a result there was lack of working capital. Moreover less profit to sustain the projects caused the beneficiaries to loan more money that had high interest from local lenders.

The Provincial Administrative Officer for Women Affairs department cited issues of lack of skills in the chosen projects. Lack of skills meant that the beneficiaries bought either more feed or less vaccines for the livestock. Poor management of projects had an effect on their viability further causing loss and more poverty. Viability was also affected by lack of marketing skills and lack of market. As indicated in the foregoing discussion, loans were not adequate to meet the demands of the projects; beneficiaries found it difficult to market their products.

Respondents were not able to carry out market research because they lacked resources to do so. Also of interest is the nature of the economy these projects operate under. Zimbabwean rural economy is mainly subsistence and the majority of people are not gainfully employed, hence there is less cash circulating in the market. This meant that there are fewer people who can buy their products at the asking price, affecting the viability of the projects.

\section{5. Challenges faced in Running the Projects}

Responding to the question based on what challenges the projects were facing, the respondents reacted as shown on Figure 4 below. $38 \%$ of the beneficiaries had problems of expensive equipment and working capital, $20 \%$ had problems of operating on low profit whilst $18 \%$ of beneficiaries' cited problems of diseases affecting their livestock and $24 \%$ cited water supply as the major hindrance to the prosperity of their projects as either water source were too far or the boreholes were non-functional.

These problems had a major bearing on the success of the projects and their sustainability. Those that cited problems of working capital were of the sentiments that markets were too far hence this made them to incorporate transport costs in the prices they charged per product.

This caused an increase in the prices of their products compared to their competitors. Beneficiaries therefore experienced loss. 


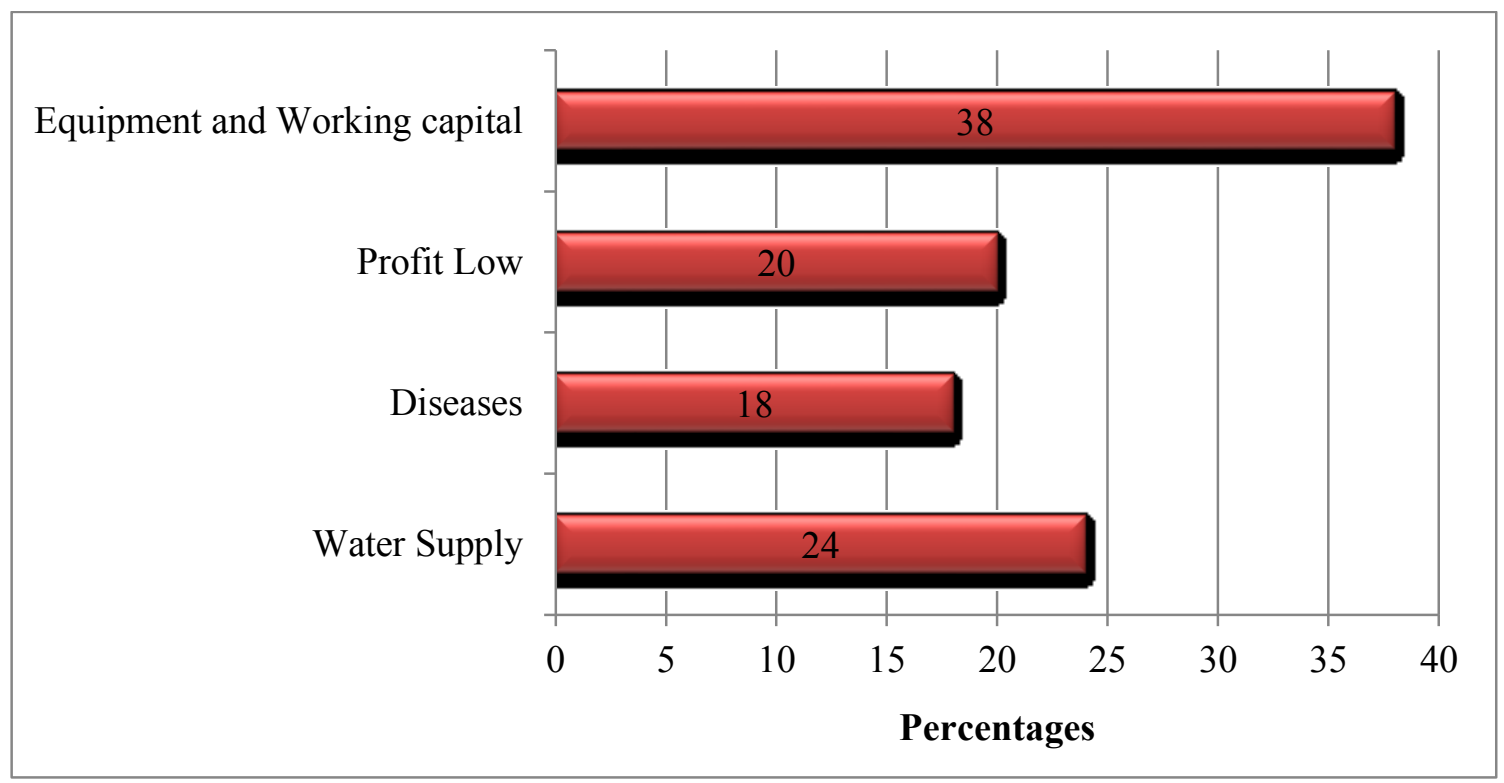

Fig. 4. Challenges faced in running the projects.

\section{6. Loan repayment Challenges}

To ascertain the sustainability of the programme, beneficiaries where asked about the challenges they faced with regards to the loan administration. One of the major challenges was on the repayment of the loan given the viability of the projects. $64 \%$ of the beneficiaries were experiencing loan repayment difficulties and $36 \%$ of the respondents were not having difficulties in servicing the loan. The Woman Development Fund loan has a life span of one year, of which the recipient is expected to have repaid it through engaging in a productive income generating activity.

However, the fact that beneficiaries were given small loans for the projects that they were engaged in, using the funds to develop livelihoods was a challenge as observed by Meade (2000) who argues that the most difficult thing is to turn a loan into profit. In fact, research reveals that the money was being diverted for other purposes, such as paying off other loans or for ceremonies and this had a negative effect on the repayment rate.

The Post Office Savings Bank officials confirmed that the repayment rate since 2010 still remains at $20 \%$ and that the $36 \%$ that said had no problems in repaying were probably sent reminders in the form of letters from the bank manager. Most of them pay when threatened whilst a few select especially those in the mining sector pay on time. This view was shared by the Provincial Development officer for the Ministry of Women Affairs who noted that beneficiaries from the mining sector could afford to pay on time since small scale mining has quicker returns as gold they produced was in high demand.

Montgomery (1996) shares the same sentiments as above in his studies in Sri-Lanka and Bangladesh. He argued that there is incompatibility between meeting the poor's needs and extending the credit.

These programs give more pressure to the recipients and resulted in added social costs. In Bangladesh, Morduch (1998) found no evidence indicating higher consumption levels or educational enrolments for children of loan holders, but merely a reduction in consumption variability across the seasons for the participants. 
In the same vein Bateman (2011) cites examples in developing countries like in India, the Balkans and Bosnia, where microcredit caused poor people to be indebted rather than helping them out of poverty. In India it has even driven the poor to take loans from local shark money lenders just to be able to pay back the microfinance loans.

The Ward Coordinators from the Ministry Of Women Affairs were of the view that most groups failed to repay the loan because the money was too much to repay since some groups dissolved as soon as the project experienced problems.

\section{7. Impact of the Fund on Poverty alleviation and Empowerment}

The study solicited for the views of the beneficiaries on whether the Women Development Fund had any positive impact in alleviating poverty and empowering women. The responses showed that $15 \%$ strongly disagreed that the fund had an impact, $28 \%$ disagreed, $16 \%$ were not sure if it made any difference in their lives, $38 \%$ surprisingly agreed that it made a difference, it reduced poverty and empowered them, and $3 \%$ strongly agreed.

Considering the fact that these beneficiaries said that the money they were loaned was too little for the projects they were engaged in, $68 \%$ had said the projects were not viable and $64 \%$ failed to repay the loan with its interest then it follows that the loan is not alleviating poverty and empowering women in these wards. The key informants were also of the view that in these particular wards the fund was not doing justice as the recipients still failed to enhance their material wellbeing reflected in indicators such as wealth, revenue earnings, assets, value of house structure, the level of cash earned, per capita expenditure on food, total household expenditure.

The key in formants cited a few reasons why the beneficiaries said poverty is reduced and that they are empowered. These reasons include fear of not being selected to benefit again from the fund or worse still be left out from benefitting from other programmes that are brought to the wards by different Ministries. Most of the beneficiaries also suffer from dependency syndrome as cited by the District Development Officer, whatever handouts are given to them they embrace whether they work for them or not.

Beneficiaries do not care to assess the effectiveness of the programme in their lives; they actually conclude that it is working for them. Some beneficiaries wanted to cover-up misuse of the fund or its diversion. If the beneficiaries said that the money did not work for them then this would mean that the relevant officers from Ministry of Women Affairs Gender and Community Development would want to conduct an evaluation program of what project was chosen and why it failed. This would mean that they will be exposed and charged for diverting the loan from its intended use.

The Sustainable Livelihood Approach states that practical intervention should facilitate the efforts of low-income households to build their livelihood assets. Examples of practical interventions include counselling programs, education, employment training, economic literacy and savings programs, and support for small business development.

The Women Development Fund as one practical intervention by the Government to support small business development does not facilitate efforts of poor beneficiaries to build their livelihoods asserts.

The findings showed that though the strategic intervention was directed toward the vulnerable, it did not work toward the goal of social and economic change as is illustrated by the Sustainable Livelihood framework. 


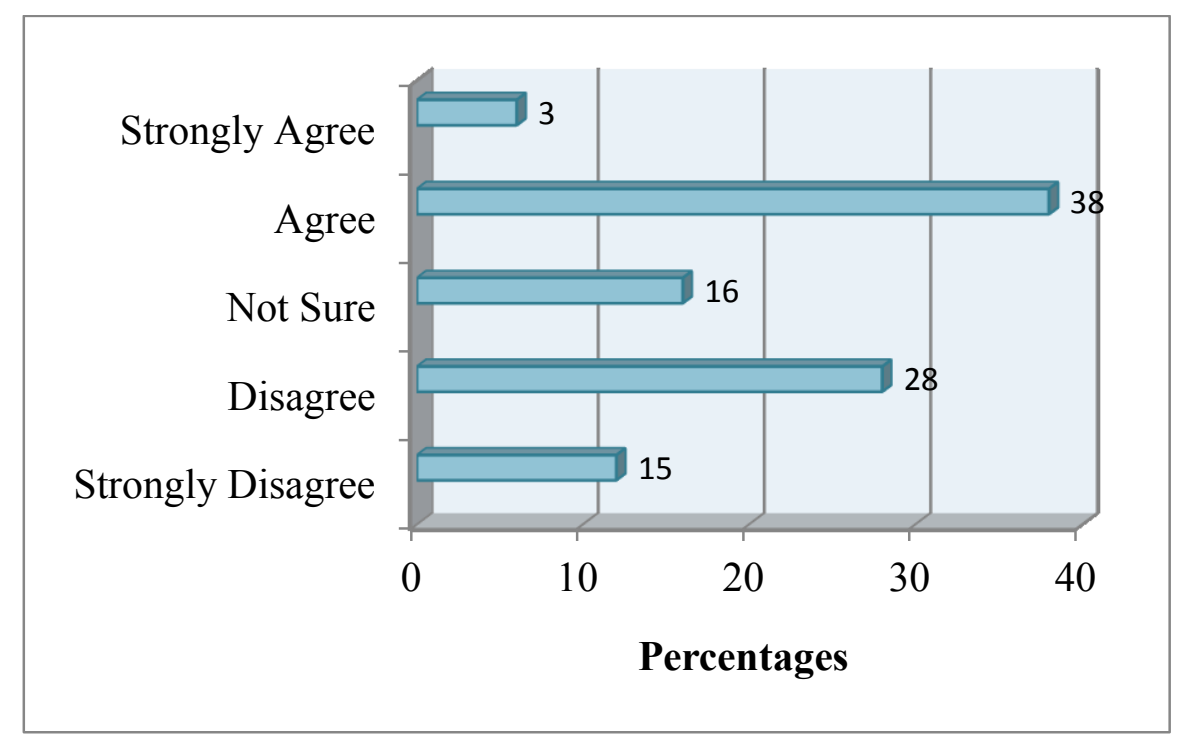

Fig. 5. Beneficiary's views on the impact of WFD.

\section{CONCLUSIONS}

In assessing the effectiveness of The Women Development Fund in the empowerment of women and the alleviation of poverty in Umguza District, the findings are in line with the view from (Bateman, 2011). He observed that microcredit caused poor people to be indebted rather than helping them out of poverty he further gives an example of India where it has even driven the poor to take loans from local shark money lenders just to be able to pay back the microfinance loans. This is also the case in Umguza District where beneficiaries are failing to repay the fund due to lack of profit and savings from the income generating projects and start borrowing from other local loan lenders to repay the Woman Development Fund. Moreover the observation by (UNDP 2005:17) that women borrowers generally tend to have higher repayment rates than men in microfinance institutions and they tend to utilise the credit for the purpose it was acquired and exercise higher repayment discipline was proven less true as is revealed in the study.

Findings proved this assertion false in that there are women benefitted from the loan but diverted the fund to their personal use. These beneficiaries expressed that the money was inadequate to incorporate working capital and to purchase vet drugs so diversion of the money was the logical thing to do. Moreover the findings were not in line with the findings from the study by Khander (1998) which found significantly higher levels of schooling for children and especially that of girls for all credit program participants.

Beneficiaries established that they were still failing to pay for education of their dependents as they had nothing in savings. They expressed concerns of actually sinking deeper and into debt by borrowing more money from local lenders to resuscitate and sustain the projects that they initiated. To them health bills were still challenges to pay as well as acquiring basic food staffs. They pointed out that they still eat 2 meals a day. The more beneficiaries sank deeper into debt the more they depended on their spouses for income. Basing on the principles of Women in Development theory which seeks to address women's practical needs by having programmes which mainly concentrate on creating employment, income-generating opportunities and improving access to education and credit. 
This is not the case in these wards mainly because of insufficient funds for the chosen projects, choice of projects and lack of training to run projects. Kabeer (2005:4712), reports that the studies of the Imp - Act (improving the impact of microfinance on poverty) programme in South Asia confirmed that access to financial services improved the economic position of households. It can be concluded that WDF is less effective in empowering women and there are changes that need to be effected to improve its impacts. One such is to train people on how to run businesses.

\section{References}

[1] Amin S. and Pebley A. R. (1994). "Gender Inequality within Households: The Impact of a Women's Development Programme in 36 Bangladeshi Village”, Bangladesh Development Studies, XXII(2); 121-140.

[2] Bateman M. (2011). Microfinance as a development and poverty reduction policy: is it everything it's cracked up to be? The Overseas Development Institute.

[3] Boserup E. et al. (1970). Women's role in economic development. St. Martin's Press, New York

[4] Dichter T. (2006). Hype and Hope: The Worrisome State of the Microcredit Movement Evidence from the Grameen Bank, in IDS Bulletine, Vol.29, No.4, Oct.

[5] Gail A. (2005). Microfinance and Development: Risk and Return from a Policy Outcome Perspective, Journal of Banking Regulation, 6(3).

[6] Kabeer N. (2005). Reverse Realities. Gender Hierarchies in Development Thought. London, Verson.

[7] Khandker Q. (1998). How Infrastructure and Financial Institutions Affect Rural Income and Poverty: Evidence from Bangladesh. Journal of Development Studies, 46(6); 1109-137.

[8] Magaji S. (2004). “Introduction to Project Evaluation “. Sanitex press Abuja

[9] Meade J. (2001). An Examination of the Microcredit Movement. Accessed from http://www.geocities.com/jasonmeade3000/Microcredit.html.

[10] Montgomery H. (2005). Meeting the Double Bottom Line: The Impact of Khushali Bank's Microfinance Programme in Pakistan. MPRA Paper

[11] Montgomery R. (1996). Disciplining or protecting the poor? Avoiding the social costs of peer pressure in micro-credit schemes. Journal of International Development, 8(2); 289-305.

[12] Morduch J. (1998). Does Mirco-finance Really Help the Poor: New Evidence from Flagship Programs in Bangladesh, Department of Economic and HIID, Harvard University and Hoover Institution, Stanford University.

[13] Naved R. (1994). 'Empowerment of Women: Listening to the Voices of Women' in the Bangladesh Development Studies Special Issue on Women, Development and Change, XXII(2\&3); 121-155, 155-179, Edited by Amin, S, BIDS, Dhaka. 
[14] Osmani L. N. K. (1998). 'The Grameen Bank Experiment: Empowerment of Women through Credit' in Afshar, Haleh (Ed.) Women and Empowerment: Illustrations from The Third World, MacMillan Press LTD, New York.

[15] Otero M. (1999) Bringing Development Back into Microfinance. Journal of Microfinance, 1(1); 8-19.18

[16] Rankin K. N. (2001). Governing development: neoliberalism, microcredit, and rational economic woman. Economy \& Society, 30(1); 18-37.

[17] Schreiner M., Colombet H .H. (2001). From Urban to Rural: Lessons for Microfinance from Argentina. Development Policy Review, 19(3); 339-354.

[18] UNDP (2005) United Nations Development Programme report.

[19] UNIDO (2003): Developing Rural and Women Entreprenuarship report.

[20] UNIFEM (2012) United Nations Fund for Women Development report.

[21] WHO (2012) World Health Organisation report.

[22] World Bank (2006) World Bank report.

[23] Zaman, H. (2001) Assessing the poverty and vulnerability impact of micro-credit in Bangladesh: a case study of BRAC. Background paper for World Bank World Development Report 2000/2001. Washington, DC: World Bank. (unpublished). 